\title{
CCR7 Receptor Expression in Mono-MAC-1 Cells: Modulation by Liver X Receptor $\alpha$ Activation and Prostaglandin $\mathrm{E}_{2}$
}

\author{
Bérengère Tanné, Stéphane Bernier, and Nancy Dumais \\ Département de Biologie, Faculté des Sciences, Université de Sherbrooke, Sherbrooke, QC, Canada J1K 2R1 \\ Correspondence should be addressed to Nancy Dumais; nancy.dumais@usherbrooke.ca
}

Received 22 August 2015; Revised 5 November 2015; Accepted 8 November 2015

Academic Editor: G. Rogler

Copyright (C) 2015 Bérengère Tanné et al. This is an open access article distributed under the Creative Commons Attribution License, which permits unrestricted use, distribution, and reproduction in any medium, provided the original work is properly cited.

Cell migration via chemokine receptor CCR7 expression is an essential function of the immune system. We previously showed that prostaglandin $\mathrm{E}_{2}\left(\mathrm{PGE}_{2}\right)$, an important immunomodulatory molecule, increases CCR7 expression and function in monocytes. Here, we explore the role of the liver X receptor $\alpha(\operatorname{LXR} \alpha)$ activation on CCR7 expression in Mono-Mac-1 (MM-1) cells in the presence of PGE 2 . To do this, MM-1 cells were stimulated with the LXR $\alpha$ synthetic agonist T0901317 in the presence or absence of $\mathrm{PGE}_{2}$. CCR7 mRNA transcription was measured using quantitative RT-PCR and protein expression was examined using flow cytometry. CCR7 function was analyzed using migration assays in response to CCL19/CCL21, which are natural ligands for CCR7. Our results show that agonist-mediated activation of LXR $\alpha$ in the presence of $\mathrm{PGE}_{2}$ increases CCR7 mRNA transcription and MM1 cell migratory capacity in response to CCL19/21. In addition, our results demonstrate that engagement of the E-prostanoids 2 and $4\left(\mathrm{EP}_{2} / \mathrm{EP}_{4}\right)$ receptors present on $\mathrm{MM}-1$ cells is responsible for the observed increase in CCR7 mRNA expression and function during LXR $\alpha$ activation. Examination of monocyte migration in response to lipid derivatives such as $\mathrm{PGE}_{2}$ and oxysterols that are produced at sites of chronic inflammation would contribute to understanding the excessive monocyte migration that characterizes atherosclerosis.

\section{Introduction}

Inflammatory monocytes are rapidly recruited to sites of inflammation, but their excessive and/or prolonged recruitment hinders the resolution of inflammation and is a hallmark of numerous diseases. Chemokines CCL19 and CCL21, which are important for cellular migration, are expressed by lymphatic endothelia as well as within lymph nodes by stromal cells, endothelial cells, and dendritic cells (DCs) [14]. These chemokines are the natural ligands of CCR7, which is expressed in DCs [5], T and B cells [6], and monocytes [7]. Mice deficient in CCL19, CCL21, or CCR7 demonstrate defective DC trafficking and altered immune responses $[8,9]$.

$\mathrm{PGE}_{2}$ modulates immune responses both in vitro and in vivo [10]. A marked increase in $\mathrm{PGE}_{2}$ production (as high as $10^{-4} \mathrm{M}$ ) is generated in response to a variety of immunological stimuli and infections with different pathogens (reviewed in [11]). The immunomodulatory molecule $\mathrm{PGE}_{2}$ appears to have a dual role in DC migration by regulating CCR7 expression and activity. Maturation-induced upregulation of CCR7 surface expression is not sufficient for monocytederived DCs (MoDCs) to migrate toward CCL19 and CCL21 $[12,13]$. Indeed, MoDC migration toward CCL19 and CCL21 was readily observed upon maturation in the presence of the proinflammatory mediator $\mathrm{PGE}_{2}$. However, $\mathrm{PGE}_{2}$ did not alter expression levels of CCR7 on mature DCs $[12,13]$. In human monocytes, $\mathrm{PGE}_{2}$ affects CCR7 mRNA expression and function $[6,14]$.

In macrophages as well as in DCs, oxysterol-mediated activation of the nuclear liver X receptor (LXR) has been shown to modulate innate immunity and tumor growth (reviewed in [15]). LXR $\beta$ is expressed ubiquitously, whereas LXR $\alpha$ is expressed in the liver, adipose tissue, adrenal glands, intestine, lungs, and cells of the myelomonocytic lineage [16]. Interestingly, it has been demonstrated that LXR-dependent effects in DCs regulate CCR7-dependent migration. Indeed, LXR $\alpha$ and LXR $\beta$, which are oxysterol-activated transcription factors, prevent TLR-induced CCR7 upregulation in MoDCs 
TABLE 1: Primers used in real-time qPCR assays.

\begin{tabular}{lcll}
\hline Target & $\mathrm{MgCl}_{2}$ & Forward primer & Reverse primer \\
\hline LXR & $3.5 \mathrm{mM}$ & $5^{\prime}$-GCTGCAAGTGGAATTCATCAACC-3 & $5^{\prime}$-ATATGTGTGCTGCAGCCTCTCCA-3 \\
CCR7 & $2 \mathrm{mM}$ & $5^{\prime}$-GTGGTGGCTCTCCTTGTCAT-3 & $5^{\prime}$-TGTGGTGTTGTCTCCGATGT-3' \\
ABCG1 & $2 \mathrm{mM}$ & $5^{\prime}$-CACCAGCCGACTGTTCTGCAT-3' & $5^{\prime}$-TGTACCGGGGAAAAGTCTGC-3' $^{\prime}$ \\
B2M & $2 \mathrm{mM}$ & $5^{\prime}$-GAGTATGCCTGCCGTGTGAA-3 & $5^{\prime}$-TGCGGCATCTTCAAACCTCC-3 $^{\prime}$ \\
hOGG1 & $3.5 \mathrm{mM}$ & $5^{\prime}$-TGGAAGAACAGGGCGGGCTA-3' & $5^{\prime}$-ATGGACATCCACGGGCACAG-3 \\
\hline
\end{tabular}

[17] and interfere with CCR7 expression on mature DCs, resulting in a dampened antitumor immune response [18]. Moreover, a recent study showed that $\mathrm{PGE}_{2}$ interferes with LXR activation, downregulates LXR $\alpha$ expression, and rescues the migratory ability of DCs to migrate toward CCR7 ligands [19]. Therefore, because lipid derivatives such as oxysterols and prostaglandins are important in DC migration, we examined whether $\mathrm{PGE}_{2}$ and LXR activation can modify CCR7-dependent migration of human monocytes.

Our results show that $\mathrm{PGE}_{2}$ and synthetic LXR $\alpha$ ligand, T0901317, strongly increase MM-1 cell migratory capacity in response to CCL19/21. Examination of monocyte migration in response to lipid derivatives, produced during chronic inflammation, would contribute to understanding the excessive monocyte migration that characterizes atherosclerosis.

\section{Materials and Methods}

2.1. Reagents. Prostaglandin $\mathrm{E}_{2}$ and the LXR agonist T0901317 were purchased from Sigma-Aldrich (St. Louis, MO, USA). The MEK kinase inhibitor PD98059 was purchased from Enzo Life Sciences (Farmingdale, NY, USA). The EP agonists butaprost, 11-deoxy-PGE , $_{1}$ and 17-phenyl-trinor-PGE $\mathrm{P}_{2}$, as well as the phosphatidylinositol 3-kinase (PI3K) inhibitor LY294002 and PKA inhibitor H-89 were obtained from Cayman Chemical (Ann Arbor, MI, USA). The blocking antibody against human CCR7 and chemokines CCL19/CCL21 were purchased from R\&D Systems (Minneapolis, MN, USA).

2.2. Cell Culture. Mono-Mac-1 cells (MM-1; ACC 252), an acute peripheral monoblastic leukemia derived cell line (German Collection of Microorganisms and Cell Cultures, Braunschweig, Germany), were cultured in RPMI 1640 media (Sigma-Aldrich) supplemented with $10 \%$ heat-inactivated fetal bovine serum (FBS), nonessential amino acids (NEAA), $1 \mathrm{mM}$ sodium pyruvate, 100 I.U. penicillin $\mathrm{G}$, and $100 \mu \mathrm{g} / \mathrm{mL}$ streptomycin (all were obtained from Wisent, St-Bruno, QC, Canada).

2.3. Blood Monocyte Isolation. Total blood mononuclear cells were isolated from the blood of healthy donors using lymphocyte separation Medium 1077 (Sigma) and washed twice in Hank's balanced salt solution (Wisent). Cells were cultured in RPMI 1640 medium, 20\% heat-inactivated FBS, and 10\% heat-inactivated human serum for $2 \mathrm{~h}$ before use. Monocytes were washed from nonadherent cells with phosphatebuffered saline (PBS). Monocytes were then enriched from peripheral blood mononuclear cells using the MACS Monocyte Isolation Kit II and MACS LS Columns (Miltenyi Biotec, Auburn, CA, USA), yielding an average purity of $98 \%$. The purity was assessed by flow cytometric analyses as recommend by the manufacturer, and isolated monocytes were fluorescently stained with CD14-FITC and anti-Biotin$\mathrm{PE}$ that labeled nonmonocytes. Blood monocytes were stimulated for the indicated times using $1 \mu \mathrm{MPGE}_{2}$ and/or $1 \mu \mathrm{M}$ T0901317.

2.4. Real-Time Quantitative Polymerase Chain Reaction ( $q$ PCR) Analyses. MM-1 cells were incubated with stimulants for the indicated times, and total RNA was extracted using Nucleospin RNA columns (Macherey-Nagel, BioLynx, Brockville, ON, Canada) according to the manufacturer's instructions. RNA ( $2 \mu \mathrm{g})$ was reverse-transcribed into cDNA in the presence of $0.5 \mu \mathrm{g}$ of oligonucleotide $\mathrm{d}(\mathrm{T})_{15}, 200$ units of M-MLV RT (Promega, Madison, WI, USA), and $250 \mu \mathrm{M}$ deoxyribonucleotide triphosphates (dNTPs) at $42^{\circ} \mathrm{C}$ for $1 \mathrm{~h}$. Amplification of human NR1H3 (LXR $\alpha), C C R 7$, and ABCG1 was performed using the SYBR Green I nucleic acid gel stain (Invitrogen, Burlington, ON, Canada) on a CFX Connect Real Time System (BIO-RAD, Mississauga, ON, Canada). Results were analyzed using the software BIO-RAD CFX Manager. qPCR reactions contained $0.25 \mu \mathrm{M}$ forward and reverse primers (Table 1), $0.1 \mathrm{mM}$ dNTPs, $2 \mathrm{mM}$ or $3.5 \mathrm{mM}$ $\mathrm{MgCl}_{2}$, and 1.25 units of Omni Klentaq (Enzymatics, Beverly, MA, USA). In each reaction, we used $8 \mu \mathrm{L}$ of a $1: 2$ dilution of each cDNA (dilutions were performed using molecular grade sterile water (Wisent)). PCR cycling conditions consisted of an initial denaturation at $95^{\circ} \mathrm{C}$ for 3 minutes and 40 cycles of $95^{\circ} \mathrm{C}$ for $10 \mathrm{sec}, 60^{\circ} \mathrm{C}$ for $40 \mathrm{sec}, 72^{\circ} \mathrm{C}$ for $40 \mathrm{sec}$, and a melting curve at $95^{\circ} \mathrm{C}$ for $10 \mathrm{sec}, 65^{\circ} \mathrm{C}$ for $5 \mathrm{sec}$, and $95^{\circ} \mathrm{C}$ for $5 \mathrm{sec}$.

2.5. Chemotaxis Assays. MM-1 cell chemotaxis was measured by migration through a polycarbonate filter ( $5 \mu \mathrm{m}$ pore size) in a 96-well transwell chambers (Millipore, Nepean, ON, Canada). The lower chamber contained either $150 \mu \mathrm{L}$ of a $300 \mathrm{ng} / \mathrm{mL}$ dilution of chemokine CCL19/CCL21 in RPMI 1640 media without FBS, NEAA, and sodium pyruvate, but complemented with $0.25 \%$ BSA, or media alone as a spontaneous migration control. The upper chamber contained 2.5 $\times 10^{5}$ cells in $75 \mu \mathrm{L}$ of medium. Chambers containing MM1 cells were incubated for $4 \mathrm{~h}$ at $37^{\circ} \mathrm{C}$. An aliquot $(150 \mu \mathrm{L})$ of cells that migrated to the bottom chamber was mixed with 1x PBS $(150 \mu \mathrm{L})$ and counted using a BD FACSCalibur flow cytometer (BD Biosciences, San Jose, CA, USA) by acquiring events for a fixed period of 60 seconds using CellQuest 
Software (BD Biosciences). The percentage of migrated cells was calculated as follows: the number of migrated cells in response to media only was subtracted from the number of migrated cells in response to CCL19/CCL21. This number was normalized to the total input of cells. Each experiment was performed in triplicate and repeated at least three times.

2.6. Flow Cytometry Analyses. MM-1 cells were collected and washed twice with PBS supplemented with 3\% bovine serum albumin (BSA). Fc receptors were blocked for 15 minutes at room temperature using $100 \mu \mathrm{L}$ of human serum (diluted $1: 5$ in $1 \mathrm{x}$ PBS) for $1 \times 10^{6}$ cells. Cells were then washed twice in PBS plus 3\% BSA. Cells were labeled with an antiCCR7 antibody conjugated with allophycocyanin (APC), or corresponding isotypes as a negative control, for 45 minutes on ice in the dark. Cells were then washed twice with PBS plus $3 \% \mathrm{BSA}$ and centrifuged 5 minutes at $10 \mathrm{~g}$ at $4^{\circ} \mathrm{C}$. For intracellular experiments, cells were collected and washed with buffer (1x PBS plus $1 \%$ BSA and $0.02 \%$ sodium azide). Fc receptors were blocked using $100 \mu \mathrm{L}$ human serum for 15 minutes at room temperature and washed with wash buffer. Cells were fixed with $200 \mu \mathrm{L} 4 \%$ paraformaldehyde for 15 minutes at $4^{\circ} \mathrm{C}$ and again washed with wash buffer. Cells were permeabilized by adding $200 \mu \mathrm{L}$ of $1 \%$ saponin to the wash buffer and then incubated for 45 minutes on ice with anti-CCR7 coupled with APC (Abcam, San Francisco, CA, USA) or the corresponding isotype controls. Cells were then washed twice with wash buffer. Fluorescence was read using a BD FACSCalibur flow cytometer (BD Biosciences) and results were analyzed using CellQuest software (BD Biosciences).

2.7. Statistical Analyses. Each experiment was performed at least three times. Statistically significant differences between experimental groups were evaluated using paired $t$-tests and $p<0.05$ was considered statistically significant. Computations were performed using GraphPad PRISM version 6.0 statistical software (GraphPad, San Diego, CA, USA).

\section{Results}

3.1. $P G E_{2}$ and LXR $\alpha$ Activation Upregulate CCR7 $m R N A$ Production and Function without Affecting CCR7 Surface Expression in MM-1 Cells. MM-1 is a human cell line with the properties of blood monocytes that can be used as a model system to study monocytic functions in vitro [20]. We first used real-time qPCR to examine whether $\mathrm{PGE}_{2}$ and $\mathrm{LXR} \alpha$ activation could modulate CCR7 transcription in MM-1 cells. MM- 1 cells were treated with $1 \mu \mathrm{M} \mathrm{PGE}$ and $1 \mu \mathrm{M}$ T0901317, a synthetic $\mathrm{LXR} \alpha$ agonist, for 8 or $24 \mathrm{~h}$ (Figure $1(\mathrm{a})$ ). As previously observed, $\mathrm{PGE}_{2}$ induces CCR7 mRNA expression with a maximal effect after stimulation for $8 \mathrm{~h}$ [7]. Treatment of MM-1 cells with T0901317 alone does not modify the expression of CCR7 mRNA. Interestingly, we found that cells treated with a combination of $\mathrm{PGE}_{2}$ and T0901317 showed significantly upregulated CCR7 mRNA transcription.

Next, we determined whether MM-1 cells can autoregulate LXR $\alpha$ expression as previously demonstrated in macrophages [21]. $L X R \alpha$ transcripts were measured using real-time qPCR following stimulation with $1 \mu \mathrm{M} \mathrm{PGE}$ and $1 \mu \mathrm{M}$ T0901317 (Figure 1(b)). We observed an increase in $L X R \alpha$ levels following treatment with $\mathrm{PGE}_{2}$ or T0901317 alone. mRNA production plateaued after $8 \mathrm{~h}$ of stimulation with $\mathrm{PGE}_{2}$ or T0901317 alone. However, MM-1 cells that were stimulated with a combination of $\mathrm{PGE}_{2}$ and $\mathrm{T} 0901317$ showed increased levels of $L X R \alpha$ mRNA after $24 \mathrm{~h}$ compared to cells stimulated with $\mathrm{PGE}_{2}$ or T0901317 alone.

We also investigated whether $\mathrm{PGE}_{2}$ in combination with T0901317 affects the expression of one $\operatorname{LXR} \alpha$ target gene, $A B C G 1$ (Figure 1(c)). As expected, ABCG1 mRNA levels were augmented when cells were treated with T0901317 alone. $\mathrm{PGE}_{2}$ had no effect on ABCG1 transcription. However, MM1 cells treated with a combination of $\mathrm{PGE}_{2}$ and T0901317 showed significantly reduced levels of $A B C G 1$ transcription.

We next established whether increased mRNA production correlates with CCR7 receptor function in MM-1 cells. MM-1 cells were treated with the stimulants for 24 or $48 \mathrm{~h}$ before migration through polycarbonate filters $(5 \mu \mathrm{m}$ pore size) for $4 \mathrm{~h}$. The chemotaxis assay results showed that $\mathrm{PGE}_{2}$ increases MM-1 cell migration to both CCR7 natural ligands CCL19 (Figure 2(a)) and CCL21 (Figure 2(b)) after treatment for $24 \mathrm{~h}$. Although the migratory capacity of MM-1 cells is sustained in response to CCL21 after $48 \mathrm{~h}$, migration in response to CCL19 appears transient. The LXR agonist alone did not affect the migratory capacity of MM1 cells in response to CCL19 whereas $24 \mathrm{~h}$ treatment with T0901317 significantly increased migration in response to CCL21. In contrast, migration of MM-1 cells treated with $\mathrm{PGE}_{2}$ and $\mathrm{T} 0901317$ for $48 \mathrm{~h}$ was increased compared to untreated cells or cells treated with $\mathrm{PGE}_{2}$ alone. For all chemotaxis assays, we confirmed the specificity of migration by incubating $\mathrm{PGE}_{2}$ - and T0901317-stimulated cells with a blocking antibody against human CCR7 for $10 \mathrm{~min}$ prior to migration assays. Blockade of CCR7 at the MM-1 cell surface completely abolished specific migration to CCL19 and CCL21 (data not shown). To further investigate the effects of $\mathrm{PGE}_{2}$ and T0901317 on CCR7 expression, we repeated migration assays with freshly isolated human blood monocytes. Results showed that monocyte migration toward CCL19 and CCL21 is increased following treatment of blood monocytes with $\mathrm{PGE}_{2}$ and T0901317 (Figure 3).

We aimed at establishing whether the CCR7 receptor is expressed at the cell surface of $\mathrm{PGE}_{2}$ - and T0901317stimulated MM-1 cells. Cells were incubated in the presence or absence of $\mathrm{PGE}_{2}$ and T0901317 for 24 and $48 \mathrm{~h}$. Surface expression of CCR7 was analyzed using flow cytometry. Our results showed that MM-1 cells basally express CCR7 (13.57\% with a MFI (mean fluorescence intensity) of 4.94). However, after $24 \mathrm{~h}$, CCR7 cell surface expression was upregulated by $1 \mu \mathrm{M} \mathrm{PGE}_{2}(31.66 \%$ with a MFI of 7.82$)$ but not by T0901317 (13.11\% with a MFI of 4.83 ) (Figure 4(a), upper panel). Similar results were observed after $48 \mathrm{~h}$ (Figure 4(b), lower panel). Statistics for CCR7 cell surface expression are presented in Table 2. Because CCR7 cell surface expression was not upregulated following the addition of $\mathrm{PGE}_{2}$ and T0901317, we performed intracellular flow cytometry assays after $24 \mathrm{~h}$ (Figure 4(b), upper panel) and 48 h (Figure 4(b), lower panel) 
TABLE 2: Statistical analyses of CCR7 surface expression in MM-1 cells.

\begin{tabular}{|c|c|c|c|c|c|c|}
\hline & Mean \% of positive cells & SD & $p$ value & Mean MFI & $\mathrm{SD}$ & $p$ value \\
\hline \multicolumn{7}{|l|}{$24 \mathrm{~h}$} \\
\hline Untreated & 16,04 & 2,21 & & 4,32 & 0,54 & \\
\hline $\mathrm{PGE}_{2}$ & 36,40 & 5,67 & 0.0044 & 9,24 & 1,55 & 0.0066 \\
\hline Т0901317 & 11,32 & 1,86 & 0.047 & 4,76 & 0,72 & 0.45 \\
\hline $\mathrm{PGE}_{2}+\mathrm{T} 0901317$ & 26,83 & 2,06 & 0.0038 & 6,68 & 1,18 & 0.035 \\
\hline \multicolumn{7}{|l|}{$48 \mathrm{~h}$} \\
\hline Untreated & 6,11 & 2,04 & & 3,32 & 0,76 & \\
\hline $\mathrm{PGE}_{2}$ & 17,81 & 3,99 & 0.011 & 7,59 & 2,13 & 0.030 \\
\hline T0901317 & 5,07 & 2,49 & 0.61 & 3,71 & 0,88 & 0.57 \\
\hline $\mathrm{PGE}_{2}+\mathrm{T} 0901317$ & 20,11 & 2,48 & 0.0016 & 8,06 & 1,69 & 0.011 \\
\hline
\end{tabular}

Data represent mean \pm standard deviation (SD) of three independent flow cytometry experiments after 24 or $48 \mathrm{~h}$ of treatment with $1 \mu \mathrm{M} \mathrm{PGE}$ and/or $1 \mu \mathrm{M}$ T0901317.

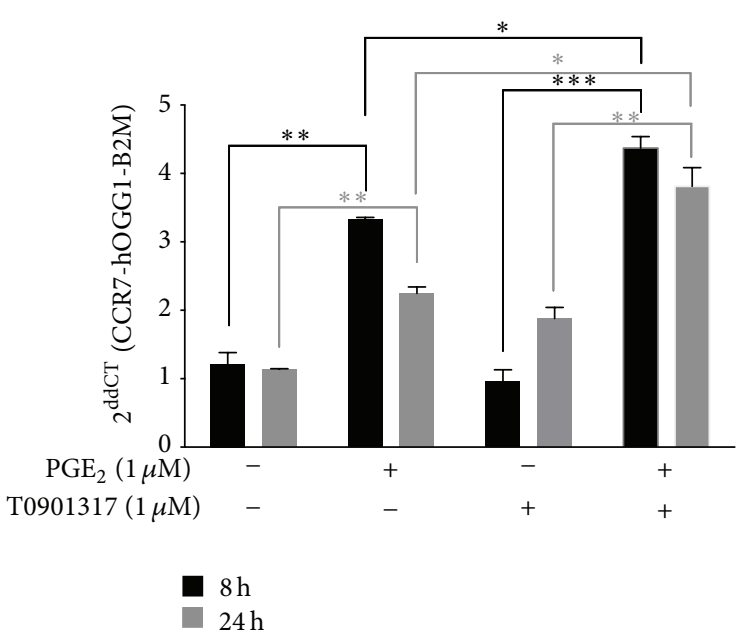

(a)

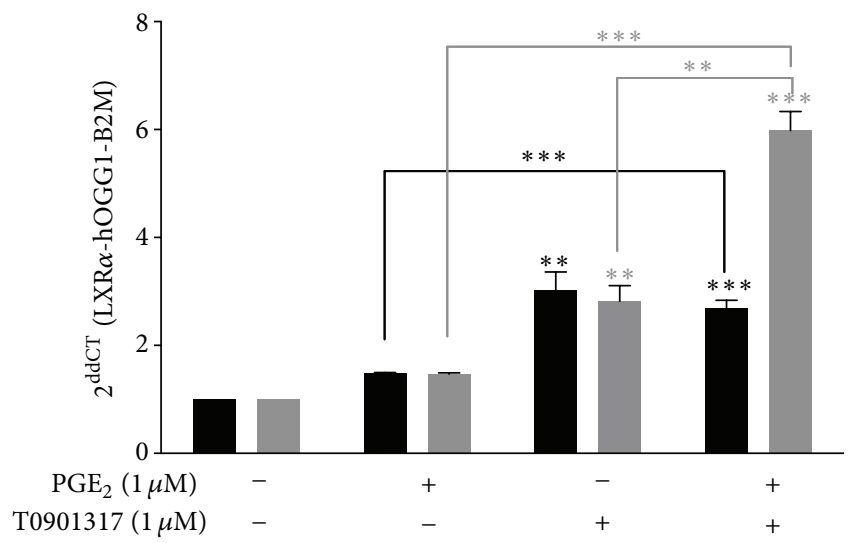

(b)

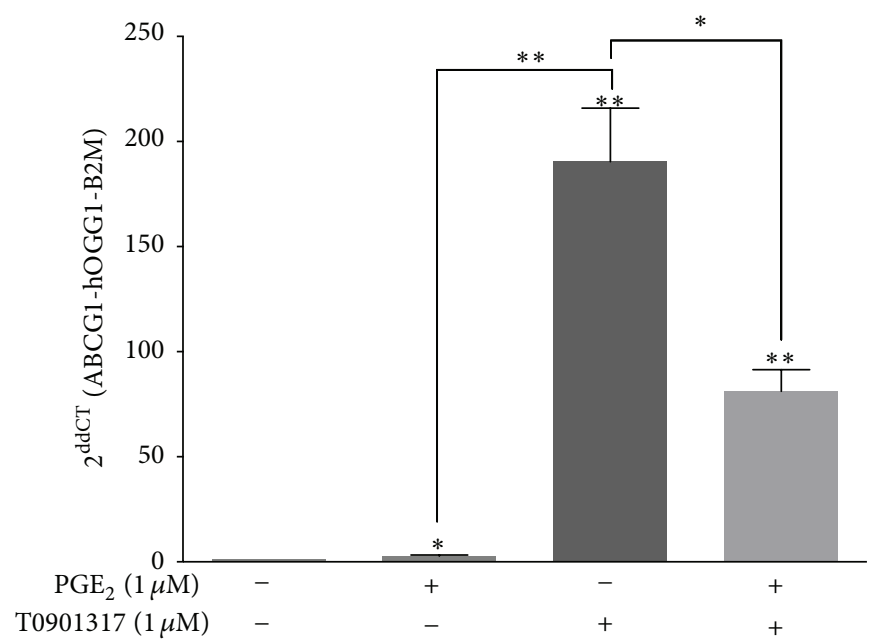

(c)

FIGURE 1: Effects of $\mathrm{PGE}_{2}$ and T0901317 on CCR7, ABCG1, and $L X R \alpha$ transcription in MM-1 cells. MM-1 cells were stimulated for $8 \mathrm{~h}$ and $24 \mathrm{~h}$ with $1 \mu \mathrm{M} \mathrm{PGE}_{2}$ and $1 \mu \mathrm{M}$ T0901317. Total RNA was extracted and examined using real-time quantitative PCR to detect CCR7 (a), ABCG1 (b), and $\operatorname{LXR} \alpha$ (c) mRNA levels. Data represent mean \pm standard deviation (SD) of three independent experiments. ${ }^{*} p<0.05,{ }^{* *} p<0.01$, and ${ }^{* * *} p<0.001$. 


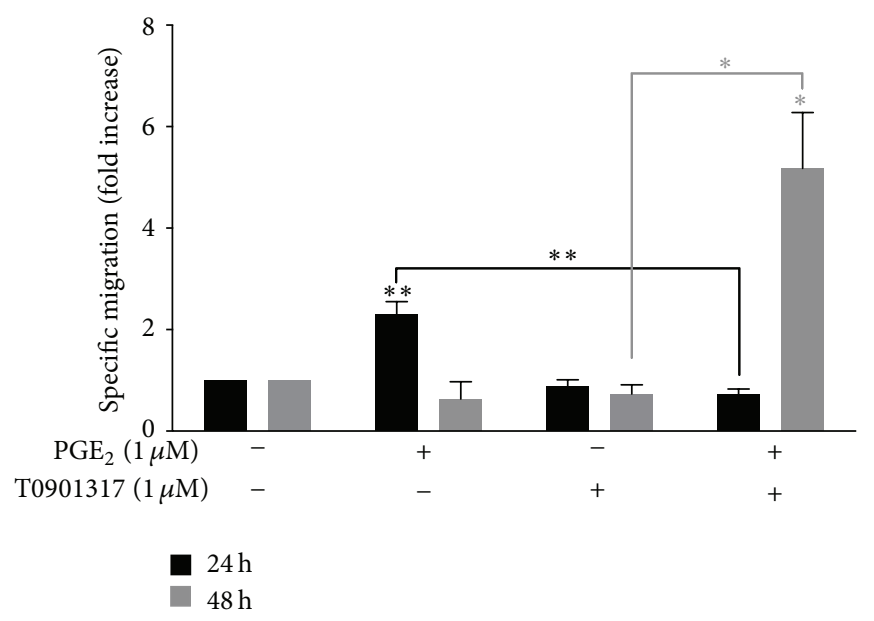

(a)

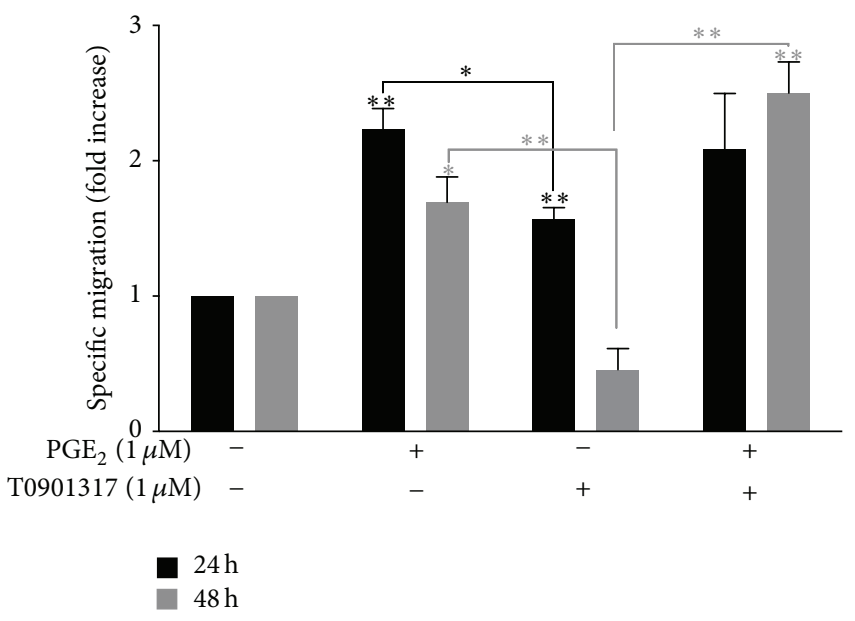

(b)

FIGURE 2: $\mathrm{PGE}_{2}$ alone and in combination with T0901317 induces functional CCR7-specific migration of MM-1 cells. Chemotaxis assays in response to $300 \mathrm{ng} / \mathrm{mL}$ CCL19 (a) or CCL21 (b) were performed in MM-1 cells stimulated for $24 \mathrm{~h}$ (filled black) or $48 \mathrm{~h}$ (filled gray) with $1 \mu \mathrm{M}$ $\mathrm{PGE}_{2}$ and $1 \mu \mathrm{M}$ T0901317. The mean number of spontaneously migrating cells (that migrated to media alone) was subtracted from the number of cells that migrated in response to CCL19 or CCL21. Data represent mean \pm SD of three independent experiments. ${ }^{*} p<0.05,{ }^{* *} p<0.01$.

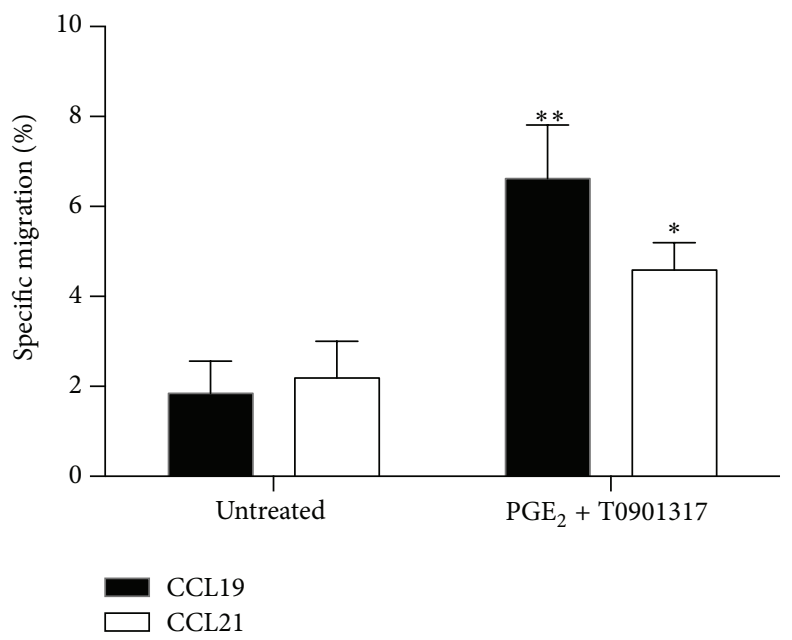

FIgURE 3: Freshly isolated monocytes migrate toward the CCR7-specific ligands CCL19 and CCL21. Chemotaxis assays using $300 \mathrm{ng} / \mathrm{mL}$ CCL19 and CCL21 were performed using human monocytes incubated in the presence or absence of $1 \mu \mathrm{M} \mathrm{PGE} 2$ and $1 \mu \mathrm{M}$ T0901317 for $48 \mathrm{~h}$. Data represent the means of three different experiments. Data represent mean $\pm \mathrm{SD}$ of three independent experiments. ${ }^{*} p<0.05,{ }^{* *} p<0.01$ compared to untreated cells.

to determine whether CCR7 receptors are trapped internally. We observed that, after $24 \mathrm{~h}$, the basal level of CCR7 is higher than the surface levels (20.87\% with a MFI of 9.96), which is similar with $\mathrm{PGE}_{2}$ treatment $(27.72 \%$ with a MFI of 12.21). However, there is no variation between treatments: In addition, there is no variation internal CCR7 expression between MM-1 cells treated with PGE $_{2}$ (24.20\% with a MFI of 10.84) or with $\mathrm{PGE}_{2}$ in combination with $\mathrm{T} 0901317$ (20.77\% with a MFI of 10.07). When MM-1 cells are treated for $48 \mathrm{~h}$, decreased levels of CCR7 are observed compared with $24 \mathrm{~h}$ treatment: untreated (3.09\% with a MFI of 3.71), $\mathrm{PGE}_{2}(6.04 \%$ with a MFI of 3.34), T0901317 (5.04\% with a MFI of 3.25), and $\mathrm{PGE}_{2}$ in combination with $\mathrm{T} 0901317$ (5.76\% with a MFI of 4.18).
3.2. The EP and $\mathrm{EP}_{4}$ Receptors Are Involved in $\mathrm{LXR} \alpha$ Activation and PGE - Induced CCR7 Transcription and Functional Migration. We previously showed that monocytes primarily express two $\mathrm{PGE}_{2}$ receptors, $\mathrm{EP}_{2}$ and $\mathrm{EP}_{4}$ [7]. Moreover, we demonstrated that both receptors are implicated in $\mathrm{PGE}_{2}$ induced CCR7 upregulation in MM-1 cells [7]. Thus, using pharmacological agonists for $\mathrm{PGE}_{2}$ receptors, we next determined whether $\mathrm{EP}_{2}$ and/or $\mathrm{EP}_{4}$ play a role in $\mathrm{PGE}_{2}$ - and T0901317-induced CCR7 migration (Figure 5). Treatment of MM-1 cells with the $\mathrm{EP}_{2}$ and $\mathrm{EP}_{4}$ agonist 11-deoxy$\mathrm{PGE}_{1}$ increased CCR7 mRNA levels compared to untreated cells (Figure 5(a)). Although 17-PT-PGE 2 is described as an $\mathrm{EP}_{1} / \mathrm{EP}_{3}\left(\mathrm{EP}_{1}>\mathrm{EP}_{3}\right)$ agonist, at high doses, 17-PT$\mathrm{PGE}_{2}$ also activates $\mathrm{EP}_{4}$ receptor $(\mathrm{Ki}=1 \mu \mathrm{M})[22,23]$. Our 
$24 \mathrm{~h}$
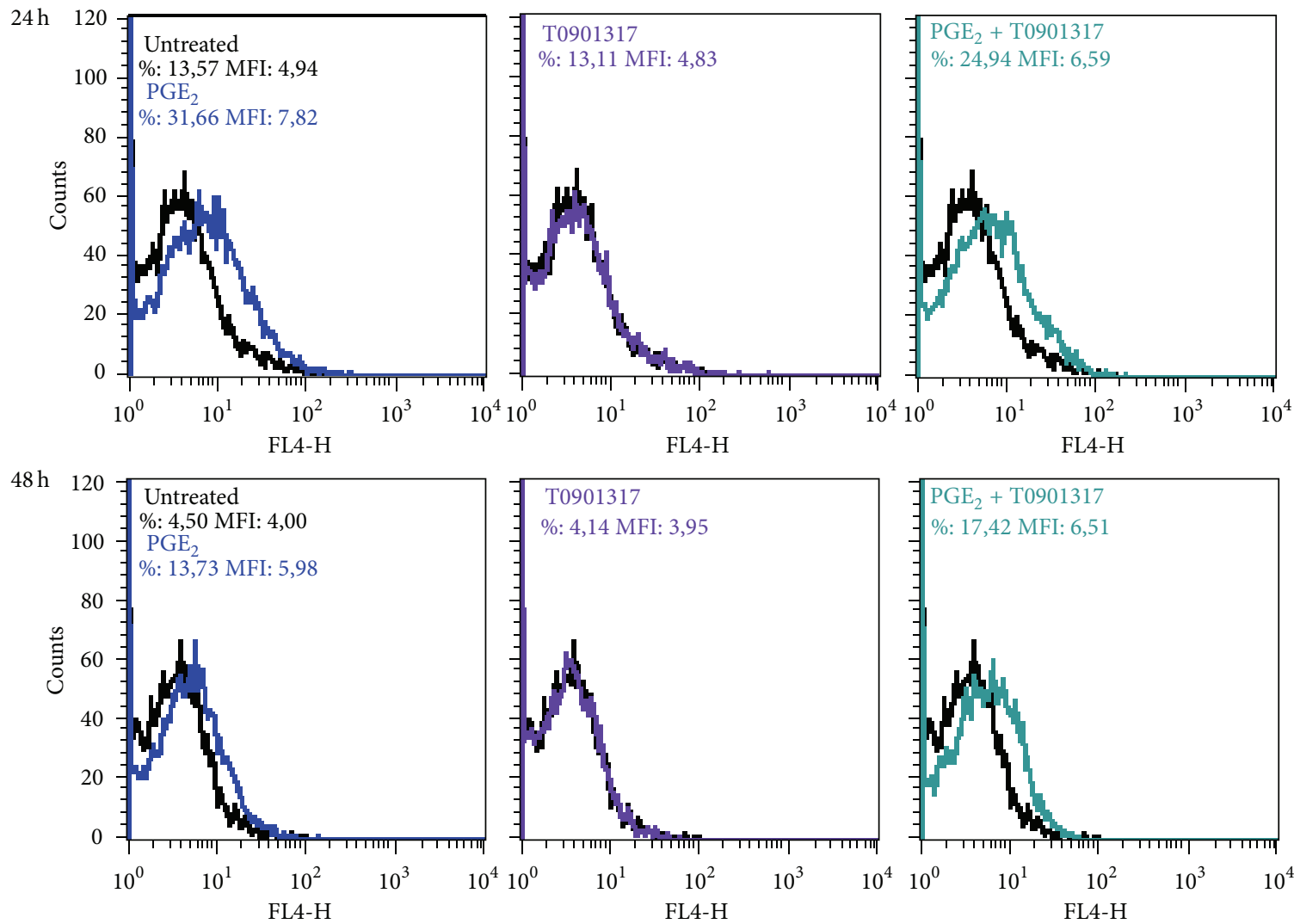

(a)
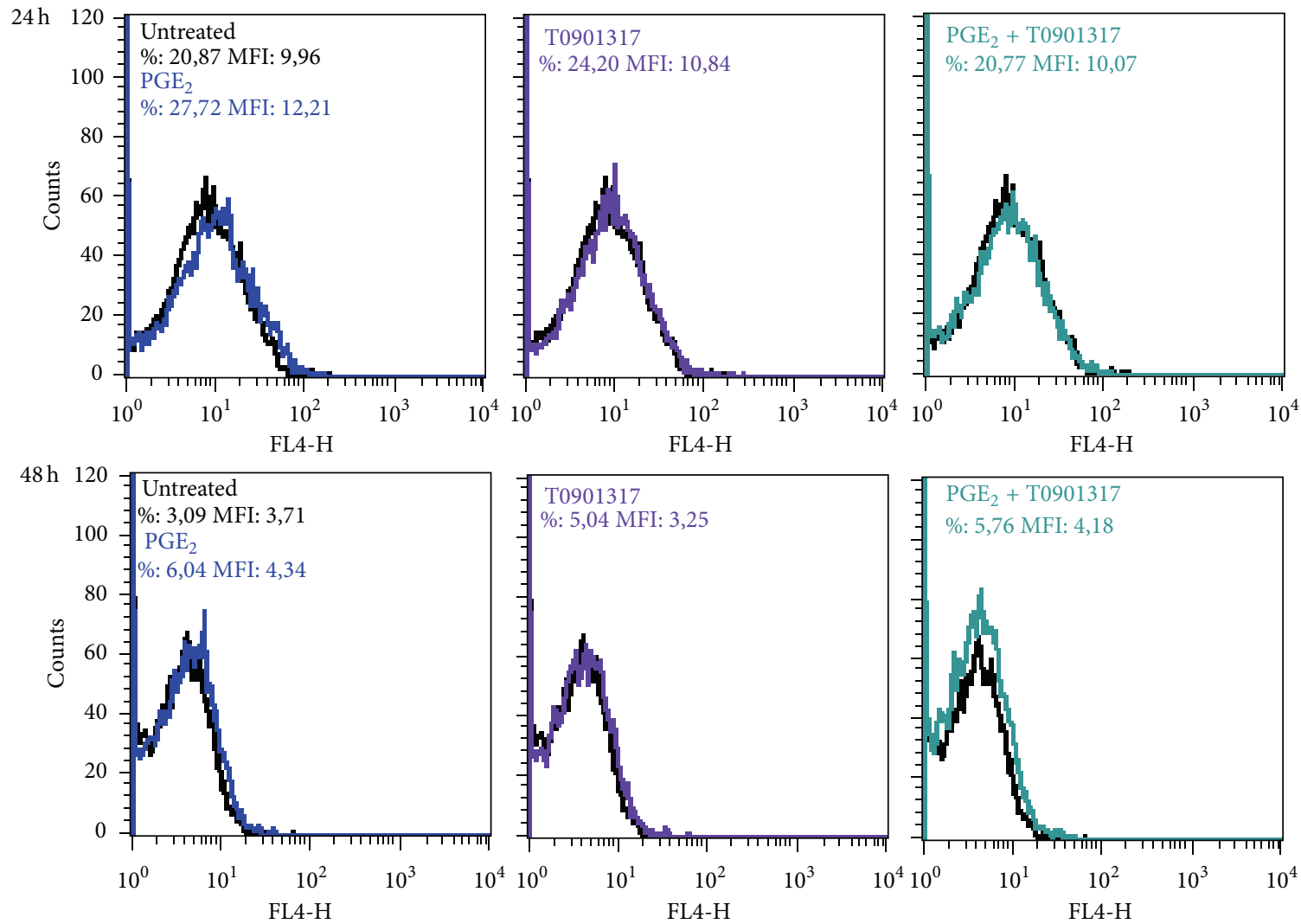

(b)

FIGURE 4: Cell surface and intracellular expression of CCR7 in MM-1 cells. CCR7 surface expression (a) or intracellular expression (b) was evaluated by flow cytometry after treatment with $1 \mu \mathrm{M} \mathrm{PGE}_{2}$ and/or $1 \mu \mathrm{M}$ T0901317 for $24 \mathrm{~h}$ or $48 \mathrm{~h}$. Data shown are from one of three representative experiments. 


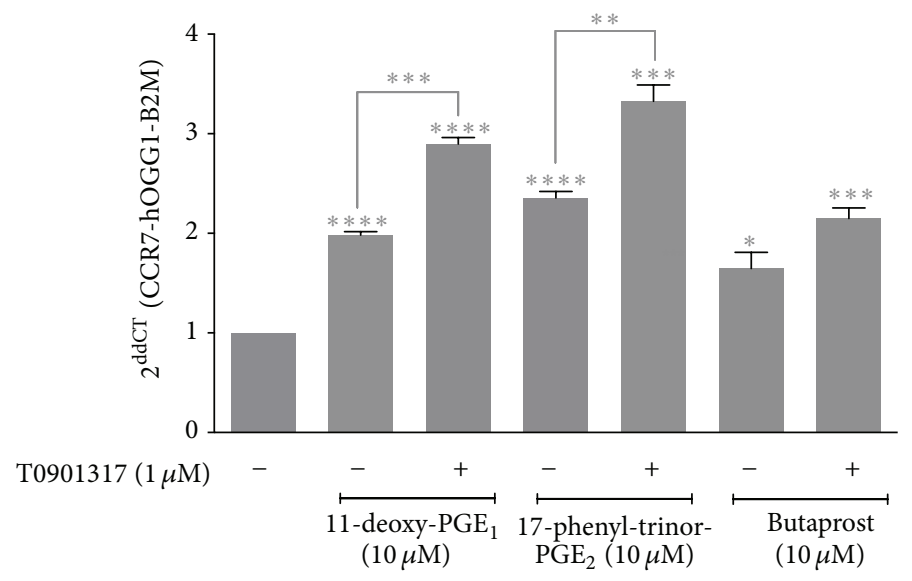

(a)

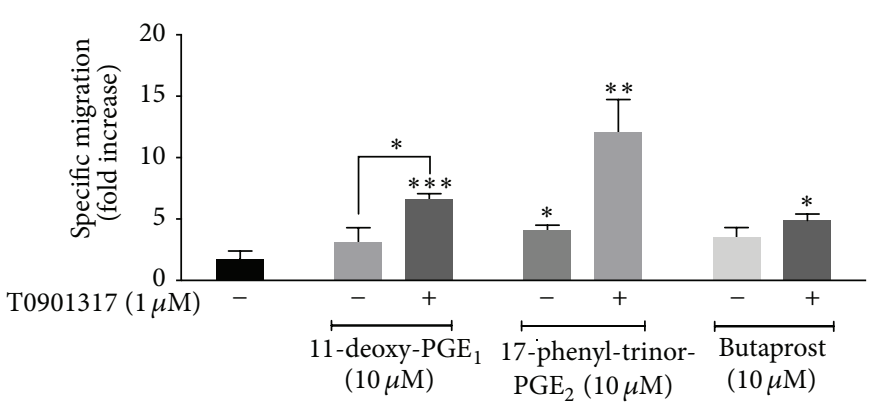

(b)

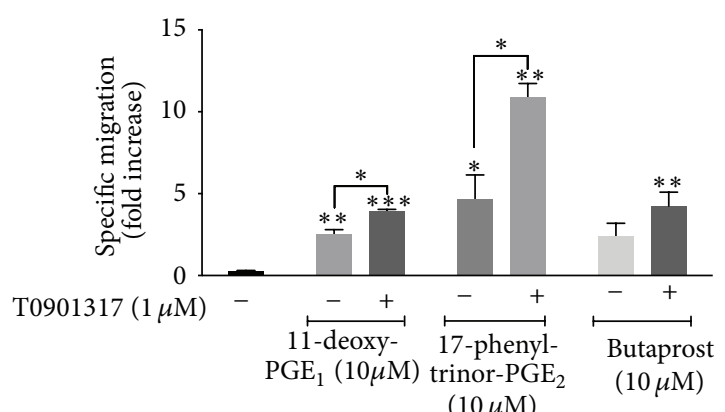

$(10 \mu \mathrm{M})$

(c)

FIGURE 5: Functional migration in response to $\mathrm{PGE}_{2}$ and T0901317 is dependent on $\mathrm{EP}_{2}$ and $\mathrm{EP}_{4}$ receptors in MM-1 cells. (a) MM-1 cells were

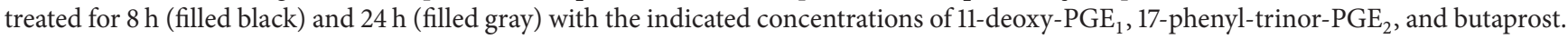
Total RNA was extracted and CCR7 transcripts were detected using real-time qPCR. Data represent mean \pm SD of three independent experiments. Chemotaxis assays in response to $300 \mathrm{ng} / \mathrm{mL}$ CCL19 (b) or CCL21 (c) were performed using MM-1 cells stimulated for $48 \mathrm{~h}$ with $1 \mu \mathrm{M}$ T0901317. The mean number of spontaneously migrating cells (that migrated to media alone) was subtracted from the number of cells that migrated in response to CCL19. Data represent mean \pm SD of three independent experiments. ${ }^{*} p<0.05,{ }^{* *} p<0.01,{ }^{* * *} p<0.001$, and ${ }^{* * * *} p<0.0001$.

results showed that 17-PT-PGE 2 significantly enhanced CCR7 expression whereas butaprost alone or in combination with T0901317 slightly increased CCR7 RNA levels compared to control. To determine which $\mathrm{PGE}_{2}$ receptors regulate the migratory response of T0901317-treated monocytes to CCL19 and CCL21, chemotaxis assays were performed on MM-1 cells in response to CCL19 (Figure 5(b)) or CCL21 (Figure 5(c)). Our results indicated that MM-1 cells migrated efficiently toward CCL19 or CCL21 when butaprost, 11-deoxy-PGE 1 , and 17-PT-PGE 2 were added to the milieu. However, the most remarkable migration occurred when $\mathrm{PGE}_{2}$-treated $\mathrm{MM}-1$ cells were cultivated in the presence of T0901317.

Because $\mathrm{EP}_{2}$ and $\mathrm{EP}_{4}$ receptors activate adenylate cyclase (AC), which then increases intracellular cAMP levels [23], we next assessed whether forskolin, a pharmacological activator of $\mathrm{AC}$, contributed to the observed induction of CCR7 mRNA (Figure 6(a)). MM-1 cells were stimulated with $100 \mu \mathrm{M}$ forskolin for $8 \mathrm{~h}$ or $24 \mathrm{~h}$ in the presence or absence of T0901317. We found that forskolin alone increases CCR7 mRNA transcription whereas forskolin combined with T0901317 did not affect CCR7 expression. AC activation did not modulate CCR7 mRNA production in T0901317-treated MM-1 cells. Thus, we searched for alternative signaling pathways. MM-1 cells were treated with H-89 (a PKA inhibitor), LY294002 (a PI3K inhibitor), or PD98059 (a MEK inhibitor) before the addition of $\mathrm{PGE}_{2}$ and T0901317 for $48 \mathrm{~h}$. Cells were used in migration assays in response to CCL19 or CCL21 (Figure 6(b)). The results showed that selective inhibition of PKA and MEK did not affect CCR7-dependent migration of MM-1 cells in response to CCL19 or 21. In contrast, inhibition of PI3K further enhanced MM-1 cell migration mediated by $\mathrm{PGE}_{2}$ and T0901317.

\section{Discussion}

In addition to modulating cholesterol homeostasis, LXRs have emerged as important regulators of inflammatory gene expression and innate immunity [21]. In inflammation, $\mathrm{PGE}_{2}$ is of particular interest because its deregulation is associated with the pathogenesis of various diseases and numerous tumor types [11, 24]. In this study, we showed for the first time that $\mathrm{PGE}_{2}$ in combination with $\mathrm{LXR} \alpha$ activation strongly 


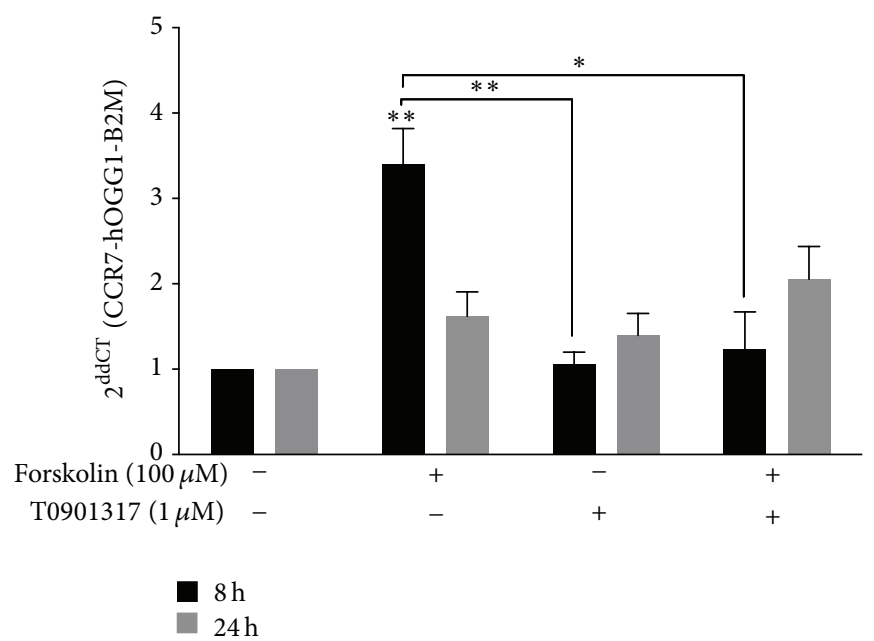

(a)

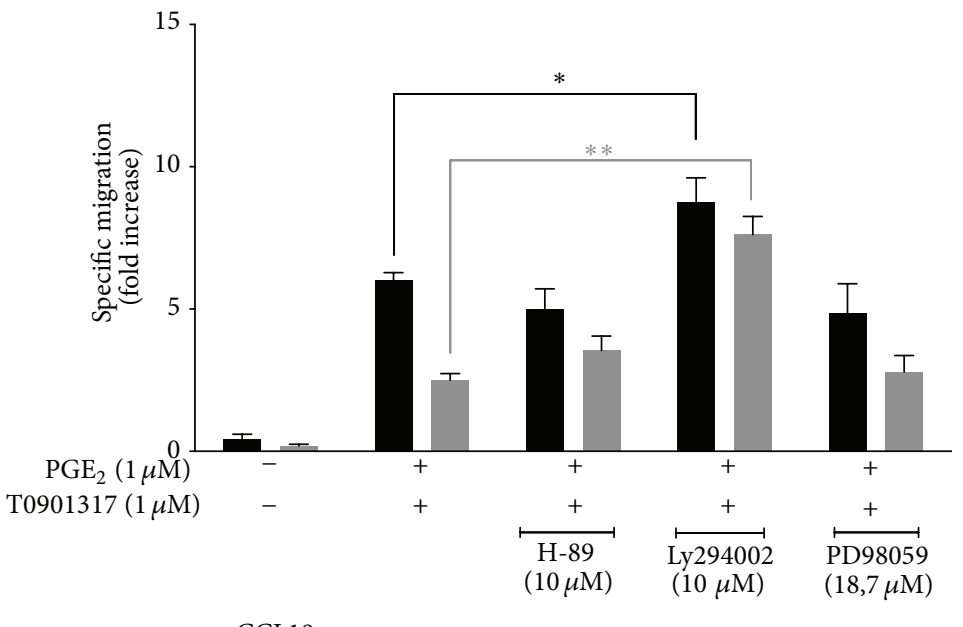

CCL19

CCL21

(b)

FIGURE 6: The role of cAMP and alternative $\mathrm{EP}_{2} / \mathrm{EP}_{4}$ signaling pathways in $\mathrm{PGE}_{2}$ - and T0901317-induced CCR7 mRNA expression and function. (a) MM-1 cells were treated for $8 \mathrm{~h}$ (filled black) and $24 \mathrm{~h}$ (filled gray) with $100 \mu \mathrm{M}$ forskolin alone or in combination with $1 \mu \mathrm{M}$ T0901317. Total RNA was extracted and CCR7 transcripts were detected using real-time qPCR. (b) Chemotaxis assays in response to $300 \mathrm{ng} / \mathrm{mL}$ CCL19 (filled black) or CCL21 (filled gray) were performed in MM-1 cells treated with the indicated concentrations of H-89, Ly294002, and PD98059 before the addition of $1 \mu \mathrm{M} \mathrm{PGE}$ and T0901317 for $48 \mathrm{~h}$. The mean number of spontaneously migrating cells (that migrated to media alone) was subtracted from the number of cells that migrated in response to CCL19 or CCL21. Data represent mean \pm SD of three independent experiments. ${ }^{*} p<0.05,{ }^{* *} p<0.01$.

increased the CCR7-dependent migratory capacity of MM1 cells, a monocytoid cell line. We showed that although CCR7 mRNA levels are upregulated following treatment with $\mathrm{PGE}_{2}$ and T0901317, there was no change in CCR7 cell surface expression. In addition, our results indicate that $\mathrm{EP}_{2}$ and $\mathrm{EP}_{4}$ receptors are implicated in $\mathrm{PGE}_{2}$-mediated $C C R 7$ transcription required for upregulating the migratory capacity of MM-1 cells in response to CCL19 and CCL21.

In mature DCs, it has been previously shown that activation of LXRs interferes with CCR7 expression, resulting in a dampened antitumor immune response [18]. Recently, Bruckner et al. [19] demonstrated that $\mathrm{PGE}_{2}$ rescues the migratory capacity of DCs cultivated in the presence of
LXR ligands to migrate toward CCR7 ligands. In contrast to these results, LXR activation in MM-1 cells by the synthetic ligand T0901317 does not modify CCR7 expression (Figure 1(a)) or CCR7-dependent migration in response to CCL19 (Figure 2(a)) or CCL21 (Figure 2(b)). However, the combination of $\mathrm{PGE}_{2}$ and T0901317 significantly increased CCR7 mRNA production and MM-1 cell migration compared to cells treated with $\mathrm{PGE}_{2}$ or T0901317 alone. In addition, blood monocytes treated $\mathrm{PGE}_{2}$ and $\mathrm{T} 0901317$ migrate in response to CCR7 specific ligands compared to untreated monocytes (Figure 3). Importantly, MM-1 surface expression of CCR7 (Figure 4(a)) did not correlate with migration efficiency (Figure 2). Indeed, other studies have shown 


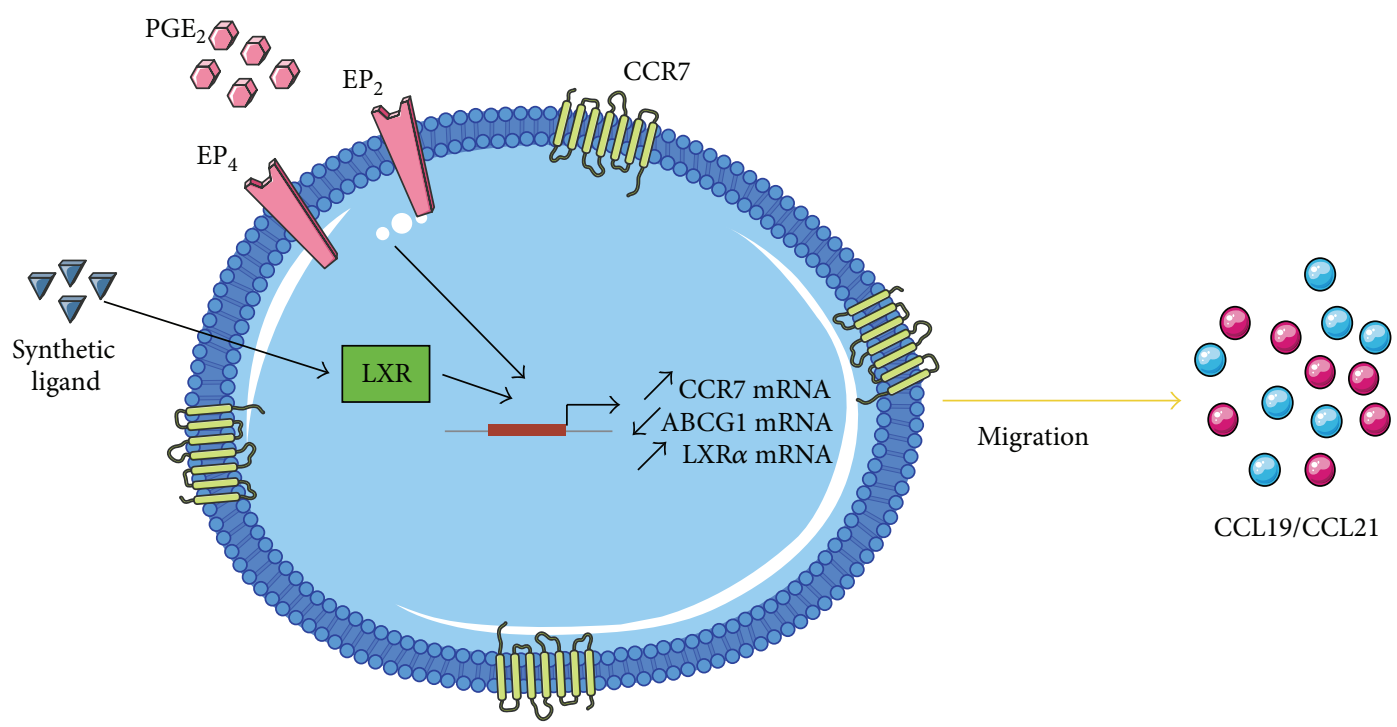

FIGURE 7: Schematic depicting effects of $\mathrm{PGE}_{2}$ and LXR activation on CCR7 functionality in MM-1 cells.

that $\mathrm{PGE}_{2}$ significantly enhances DC migration through an unknown mechanism that does not depend on the magnitude of CCR7 expression [12, 25, 26]. This phenomenon is also observed with MoDCs matured in the presence of both $\mathrm{PGE}_{2}$ and T0901317 [19]. Thus, our results in monocytes are consistent with those observed by other groups in DCs. In addition, flow cytometry analyses were also performed to detect intracellular changes in CCR7 protein expression (Figure 4(b)). However, no changes in expression were detectable. Together, our results demonstrate that LXR activation and $\mathrm{PGE}_{2}$ stimulation of MM-1 cells profoundly affect monocyte migration in response to CCL19 and CCL21. Further studies are required to examine the effect of LXR activation in the presence of $\mathrm{PGE}_{2}$ on CCR7-dependent migration of freshly isolated blood monocytes from healthy donors.

In macrophages, LXR activation results in the synthesis of the cholesterol efflux transporter ABCG1 as well as of LXR $\alpha$ itself through an autoregulatory mechanism [21]. In DCs, PGE $_{2}$ downregulated basal expression of $L X R \alpha$ but also inhibited T0901317-mediated autoinduction of $L X R \alpha$ [19]. In addition, T0901317-mediated ABCG1 induction was also significantly reduced in MoDCs matured in the presence of $\mathrm{PGE}_{2}$ [19]. In our study, we observed that $\mathrm{PGE}_{2}$ did not modulate ABCG1 mRNA production whereas T0901317 alone significantly affected transcription (Figure 1(b)). In contrast, in MM-1 cells stimulated with $\mathrm{PGE}_{2}$ and $\mathrm{T} 0901317$ for $24 \mathrm{~h}$, we observed significantly reduced $A B C G 1 \mathrm{mRNA}$ production. In MM- 1 cells, LXR $\alpha$ activation upregulated $L X R \alpha$ mRNA expression but $\mathrm{PGE}_{2}$ had no effect. In contrast to results observed in DCs [19], $24 \mathrm{~h}$ treatment with $\mathrm{PGE}_{2}$ and T0901317 strongly increased $L X R \alpha$ mRNA transcription. Our results demonstrated that the addition of $\mathrm{PGE}_{2}$ to T0901317-treated MM-1 cells reduced ABCG1 mRNA production. Because $L X R \alpha$ expression was increased after MM-1 cells were treated with $\mathrm{PGE}_{2}$ and T0901317 (Figure 1(c)), the effect on ABCG1 is likely LXR $\alpha$-independent. It has been shown that ABCG1 and
ABCG4 act in concert with ABCA1 to maximize removal of excess cholesterol from cells [27]. Taken together, our results suggest that the presence of $\mathrm{PGE}_{2}$ and oxysterols negatively impacts cholesterol efflux in monocytes. Moreover, the presence of these two lipids derivatives may favor intracellular cholesterol accumulation, thereby leading to deregulation of cholesterol homeostasis in monocytes. However, further studies are needed to clarify the mechanisms underlying the observed modulation of $A B C G 1$ by $\mathrm{PGE}_{2}$ and $\mathrm{LXR} \alpha$ ligands in monocytes.

The $\mathrm{EP}_{2}$ and $\mathrm{EP}_{4}$ receptors were previously shown to be important for CCR7 expression in mature MoDCs [13, 19, 25] and monocytes [7]. Here, our results showed that $\mathrm{PGE}_{2}$ binding to the $\mathrm{EP}_{4}$ receptor subtype, and to a lesser extent $\mathrm{EP}_{2}$, triggered signals that led to CCR7 mRNA expression and CCR7-dependent migration of MM-1 cells cultivated in the presence of the LXR $\alpha$ synthetic ligand (Figure 5). Interestingly, our data showed that $\mathrm{PGE}_{2}$ - and T0901317-upregulation of CCR7 expression and function is independent of the cAMP/PKA or MEK branches of $\mathrm{EP}_{2} / \mathrm{EP}_{4}$ signaling (Figure 6). However, we showed that inhibition of the PI3K pathway is responsible for enhanced CCR7dependent MM-1 cell migration. Thus, our results suggest the contribution of other signaling pathways.

In summary, our results demonstrate that $\mathrm{PGE}_{2}$, in combination with LXR $\alpha$ activation, increased CCR7-dependent migration of MM-1 cells (Figure 7). Lipid derivatives, including $\mathrm{PGE}_{2}$ and oxysterols, may also favor cholesterol accumulation in monocytes. Therefore, our results may have important implications regarding the mechanisms that contribute to atherosclerosis. However, further studies are needed to better understand the role of lipid derivatives produced during inflammation.

\section{Conflict of Interests}

The authors declare that there is no conflict of interests. 


\section{Acknowledgment}

This study was supported by the Canadian Institutes of Health Research (Funding Reference no. 123681).

\section{References}

[1] M. D. Gunn, K. Tangemann, C. Tam, J. G. Cyster, S. D. Rosen, and L. T. Williams, "A chemokine expressed in lymphoid high endothelial venules promotes the adhesion and chemotaxis of naive T lymphocytes," Proceedings of the National Academy of Sciences of the United States of America, vol. 95, no. 1, pp. 258263, 1998.

[2] S. A. Luther, H. L. Tang, P. L. Hyman, A. G. Farr, and J. G. Cyster, "Coexpression of the chemokines ELC and SLC by T zone stromal cells and deletion of the ELC gene in the plt/plt mouse," Proceedings of the National Academy of Sciences of the United States of America, vol. 97, no. 23, pp. 12694-12699, 2000.

[3] V. N. Ngo, H. L. Tang, and J. G. Cyster, "Epstein-Barr virusinduced molecule 1 ligand chemokine is expressed by dendritic cells in lymphoid tissues and strongly attracts naive T cells and activated B cells," The Journal of Experimental Medicine, vol. 188, no. 1, pp. 181-191, 1998.

[4] J. V. Stein, A. Rot, Y. Luo et al., "The CC chemokine thymusderived chemotactic agent 4 (TCA-4, secondary lymphoid tissue chemokine, 6Ckine, exodus-2) triggers lymphocyte function-associated antigen 1-mediated arrest of rolling $\mathrm{T}$ lymphocytes in peripheral lymph node high endothelial venules," The Journal of Experimental Medicine, vol. 191, pp. 61-76, 2000.

[5] H. Saeki, A. M. Moore, M. J. Brown, and S. T. Hwang, "Cutting edge: secondary lymphoid-tissue chemokine (SLC) and CC chemokine receptor 7 (CCR7) participate in the emigration pathway of mature dendritic cells from the skin to regional lymph nodes," Journal of Immunology, vol. 162, no. 5, pp. 24722475, 1999.

[6] R. A. Warnock, J. J. Campbell, M. E. Dorf, A. Matsuzawa, L. M. McEvoy, and E. C. Butcher, "The role of chemokines in the microenvironmental control of T versus B cell arrest in Peyer's patch high endothelial venules," The Journal of Experimental Medicine, vol. 191, no. 1, pp. 77-88, 2000.

[7] S. C. Côté, S. Pasvanis, S. Bounou, and N. Dumais, "CCR7specific migration to CCL19 and CCL21 is induced by $\mathrm{PGE}_{2}$ stimulation in human monocytes: involvement of $\mathrm{EP}_{2} / \mathrm{EP}_{4}$ receptors activation," Molecular Immunology, vol. 46, no. 13, pp. 2682-2693, 2009.

[8] R. Förster, A. Schubel, D. Breitfeld et al., "CCR7 coordinates the primary immune response by establishing functional microenvironments in secondary lymphoid organs," Cell, vol. 99, no. 1, pp. 23-33, 1999.

[9] M. D. Gunn, S. Kyuwa, C. Tam et al., "Mice lacking expression of secondary lymphoid organ chemokine have defects in lymphocyte homing and dendritic cell localization," The Journal of Experimental Medicine, vol. 189, no. 3, pp. 451-460, 1999.

[10] J. S. Goodwin and D. R. Webb, "Regulation of the immune response by prostaglandins," Clinical Immunology and Immunopathology, vol. 15, no. 1, pp. 106-122, 1980.

[11] B. Rocca and G. A. FitzGerald, "Cyclooxygenases and prostaglandins: shaping up the immune response," International Immunopharmacology, vol. 2, no. 5, pp. 603-630, 2002.

[12] E. Scandella, Y. Men, S. Gillessen, R. Förster, and M. Groettrup, "Prostaglandin E2 is a key factor for CCR7 surface expression and migration of monocyte-derived dendritic cells," Blood, vol. 100, no. 4, pp. 1354-1361, 2002.

[13] T. Luft, M. Jefford, P. Luetjens et al., "Functionally distinct dendritic cell (DC) populations induced by physiologic stimuli: prostaglandin $\mathrm{E}_{2}$ regulates the migratory capacity of specific $\mathrm{DC}$ subsets," Blood, vol. 100, no. 4, pp. 1362-1372, 2002.

[14] M.-A. Allaire and N. Dumais, "Involvement of the MAPK and RhoA/ROCK pathways in $\mathrm{PGE}_{2}$-mediated CCR7-dependent monocyte migration," Immunology Letters, vol. 146, no. 1-2, pp. 70-73, 2012.

[15] C. Traversari, S. Sozzani, K. R. Steffensen, and V. Russo, "LXRdependent and -independent effects of oxysterols on immunity and tumor growth," European Journal of Immunology, vol. 44, no. 7, pp. 1896-1903, 2014.

[16] N. Y. Kalaany and D. J. Mangelsdorf, "LXRs and FXR: the yin and yang of cholesterol and fat metabolism," Annual Review of Physiology, vol. 68, pp. 159-191, 2006.

[17] T. M. Hanley, W. B. Puryear, S. Gummuluru, and G. A. Viglianti, "PPAR $\gamma$ and LXR signaling inhibit dendritic cell-mediated HIV-1 capture and trans-infection," PLoS Pathogens, vol. 6, no. 7, Article ID e1000981, 2010.

[18] E. J. Villablanca, L. Raccosta, D. Zhou et al., "Tumormediated liver X receptor- $\alpha$ activation inhibits CC chemokine receptor-7 expression on dendritic cells and dampens antitumor responses," Nature Medicine, vol. 16, no. 1, pp. 98-105, 2010.

[19] M. Bruckner, D. Dickel, E. Singer, and D. F. Legler, "Converse regulation of CCR7-driven human dendritic cell migration by prostaglandin $\mathrm{E}_{2}$ and liver $\mathrm{X}$ receptor activation," European Journal of Immunology, vol. 42, no. 11, pp. 2949-2958, 2012.

[20] K. G. Steube, D. D. Teepe, C. Meyer, M. Zaborski, and H. G. Drexler, "A model system in haematology and immunology: the human monocytic cell line MONO-MAC-1," Leukemia Research, vol. 21, no. 4, pp. 327-335, 1997.

[21] S. J. Bensinger and P. Tontonoz, "Integration of metabolism and inflammation by lipid-activated nuclear receptors," Nature, vol. 454, no. 7203, pp. 470-477, 2008.

[22] S. Gerlo, P. Verdood, B. Gellersen, E. L. Hooghe-Peters, and R. Kooijman, "Mechanism of prostaglandin (PG)E2-induced prolactin expression in human T cells: cooperation of two PGE2 receptor subtypes, E-prostanoid (EP) 3 and EP4, via calciumand cyclic adenosine $5^{\prime}$-monophosphate-mediated signaling pathways," Journal of Immunology, vol. 173, no. 10, pp. 59525962, 2004.

[23] S. Narumiya, Y. Sugimoto, and F. Ushikubi, "Prostanoid receptors: structures, properties, and functions," Physiological Reviews, vol. 79, no. 4, pp. 1193-1226, 1999.

[24] S. G. Harris, J. Padilla, L. Koumas, D. Ray, and R. P. Phipps, "Prostaglandins as modulators of immunity," Trends in Immunology, vol. 23, no. 3, pp. 144-150, 2002.

[25] D. F. Legler, P. Krause, E. Scandella, E. Singer, and M. Groettrup, "Prostaglandin $\mathrm{E}_{2}$ is generally required for human dendritic cell migration and exerts its effect via EP2 and EP4 receptors," The Journal of Immunology, vol. 176, no. 2, pp. 966-973, 2006.

[26] R. Muthuswamy, J. Mueller-Berghaus, U. Haberkorn, T. A. Reinhart, D. Schadendorf, and P. Kalinski, "PGE2 transiently enhances DC expression of CCR7 but inhibits the ability of DCs to produce CCL19 and attract naive T cells," Blood, vol. 116, no. 9, pp. 1454-1459, 2010.

[27] A. M. Vaughan and J. F. Oram, "ABCA1 and ABCG1 or ABCG4 act sequentially to remove cellular cholesterol and generate cholesterol-rich HDL," Journal of Lipid Research, vol. 47, no. 11, pp. 2433-2443, 2006. 


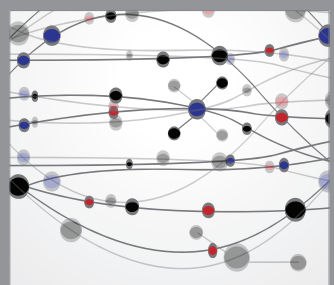

The Scientific World Journal
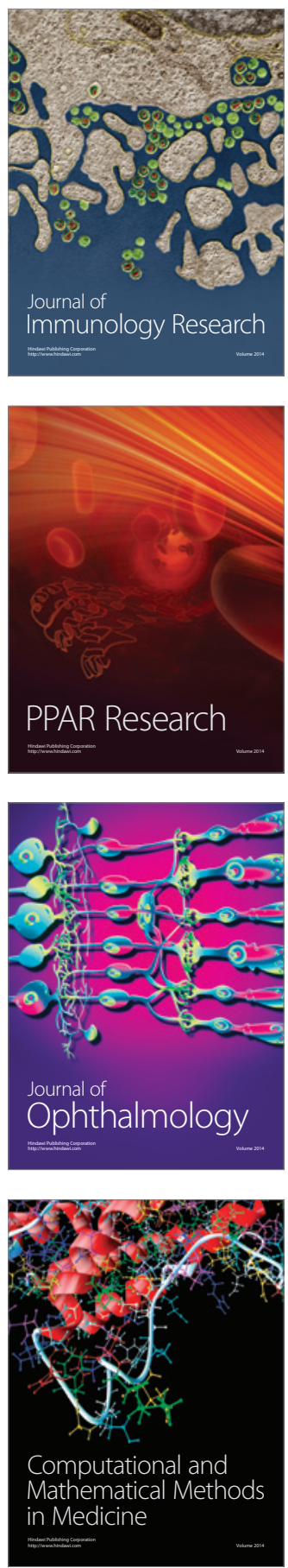

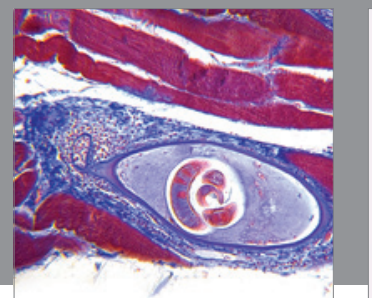

Gastroenterology

Research and Practice
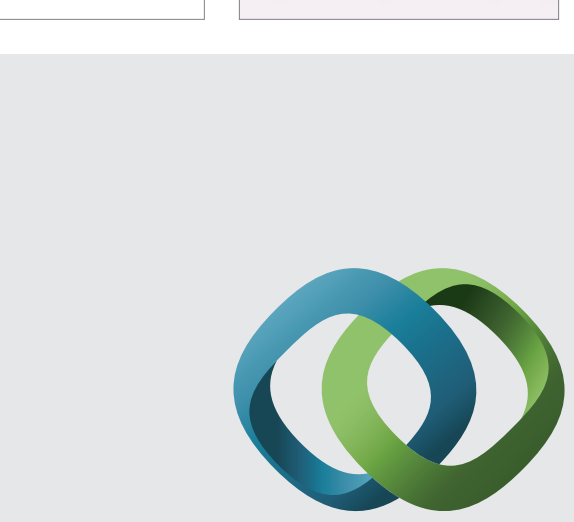

\section{Hindawi}

Submit your manuscripts at

http://www.hindawi.com
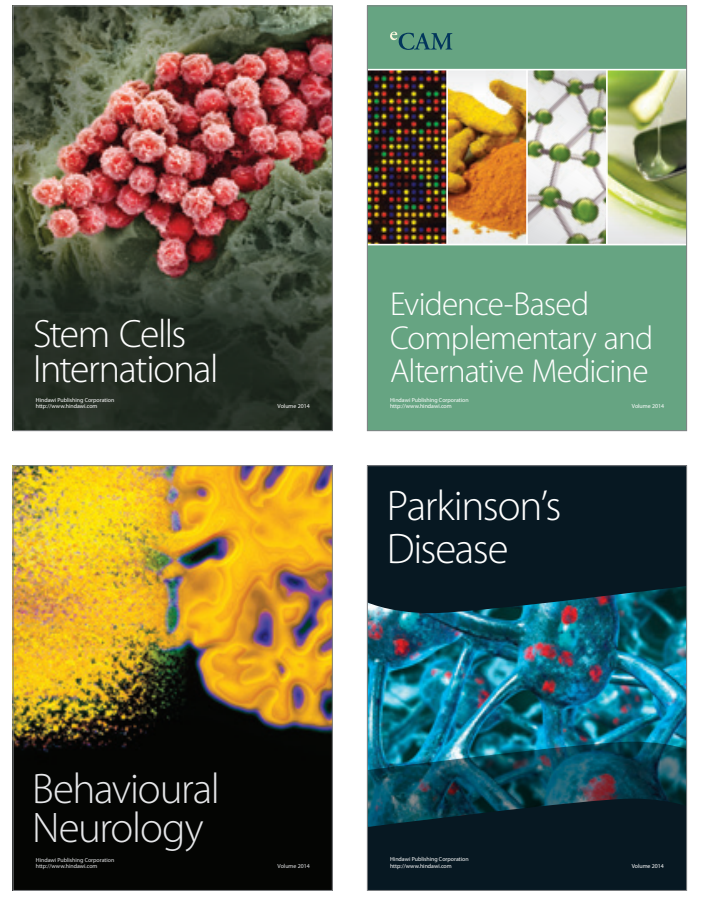
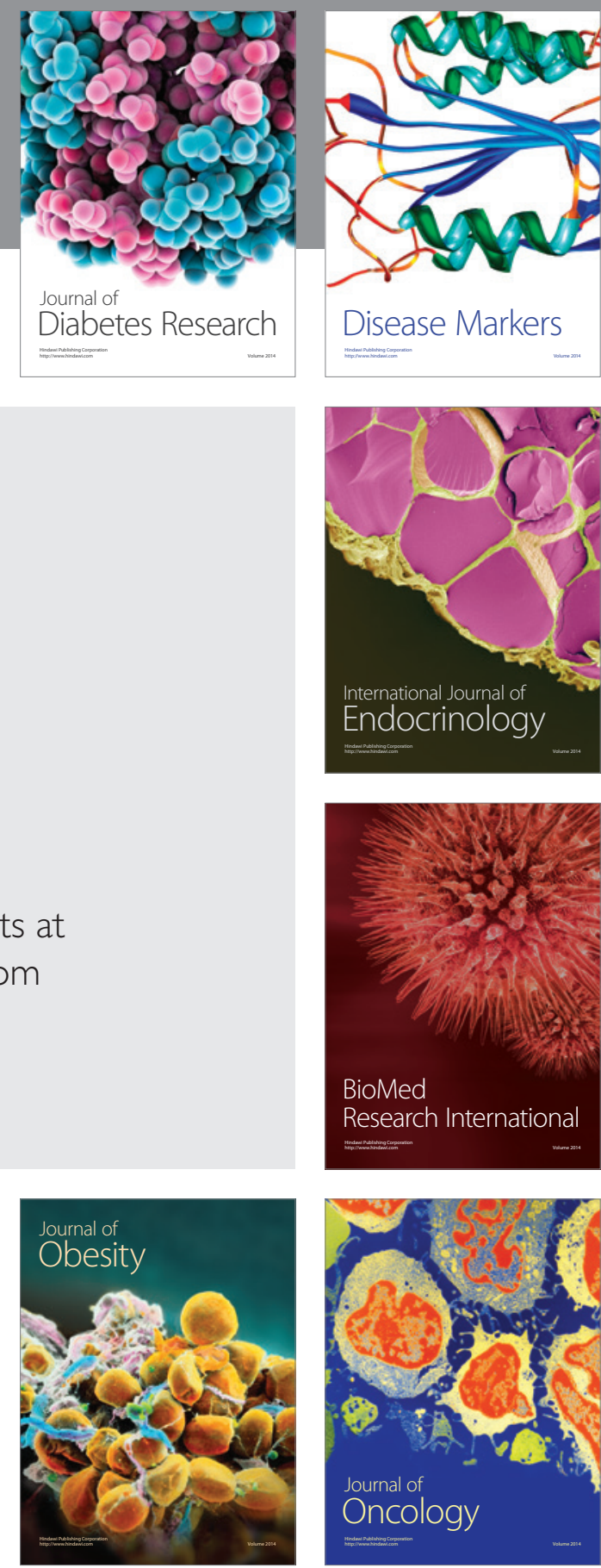

Disease Markers
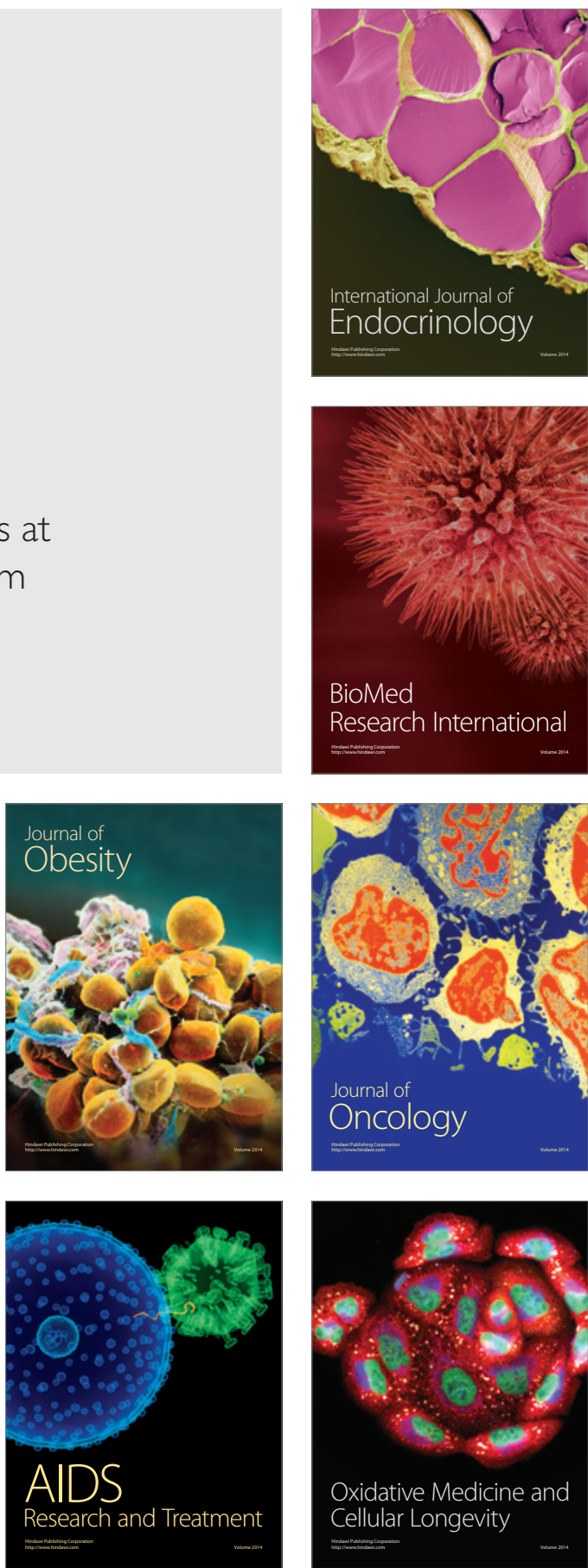